\title{
ARTYKUŁY
}

\section{JOHN RAWLS: UZASADNIENIE PRAKTYCZNE KONCEPCJI SPRAWIEDLIWOŚCI I REFLEKSYJNA RÓWNOWAGA*}

\begin{abstract}
Streszczenie. W artykule autor podejmuje dwie istotne kwestie dla zrozumienia natury uzasadnienia praktycznego. Pierwsza z nich to wyjaśnienie natury uzasadnienia praktycznego jako porozumienia między obywatelami społeczeństwa demokratycznego co do warunków (zasad) działania politycznego. Druga z nich dotyczy wyjaśnienia tego, czym jest refleksyjna równowaga.
\end{abstract}

Słowa kluczowe: John Rawls, praktyczne uzasadnienie, refleksyjna równowaga

\section{Natura praktycznego uzasadnienia. 2. Refleksyjna równowaga.}

Jednym z problemów silnie obecnych w filozofii Johna Rawlsa - począwszy od Outline of a Decision Procedure for Ethics ${ }^{1}$, a skończywszy na Liberalizmie politycznym ${ }^{2}$ - jest problem uzasadnienia. A dokładniej rzecz ujmując, problem uzasadnienia danej koncepcji sprawiedliwości z jednej strony, czyli uzasadnienia praktycznego, i wyjaśnienia, na czym owo uzasadnienie ma polegać $\mathrm{z}$ drugiej. $\mathrm{W}$ niniejszym tekście zajmę się przede wszystkim wyjaśnieniem tego, czym według autora Teorii sprawiedliwości $i^{3}$ jest uzasadnienie praktyczne. Zacznę od przedstawienia natury uzasadnienia praktycznego, rozumianej

* Podstawę niniejszego artykułu stanowi moja rozprawa doktorska: John Rawls - w poszukiwaniu normatywnych podstaw demokracji. Artykuł ten stanowi część pierwszą cyklu, poświęconą problematyce uzasadnienia w filozofii praktycznej Rawlsa. Część druga poświęcona będzie Rawlsowskiemu kontraktualizmowi i konstruktywizmowi.

1 J. Rawls, Outline of a Decision Procedure for Ethics, Philosophical Review 60(1951), 177-197.

2 Tenże, Liberalizm polityczny, tłum. z ang. A. Romaniuk, Wydawnictwo Naukowe PWN, Warszawa 1999.

3 Tenże, Teoria sprawiedliwości, tłum. z ang. M. Panufnik, J. Pasek, A. Romaniuk, Wydawnictwo Naukowe PWN, Warszawa 1994. 
przez Rawlsa jako porozumienie co do warunków działania, po czym przejdę do wyjaśnienia, czym jest refleksyjna równowaga, by wyjaśnić (w II części tekstu), jaką rolę w jej ustanowieniu odgrywa kontraktualistyczna oraz konstruktywistyczna metoda uzasadnienia.

Zanim jednak przejdę do przedstawienia natury uzasadnienia praktycznego, wyjaśnię rzecz następującą. W twórczości Johna Rawlsa zwykło się wyróżniać dwa okresy, które umownie można nazwać okresem Teorii sprawiedliwości oraz okresem Liberalizmu politycznego. Tym, co je różni, to tzw. „polityczny zwrot” z okresu późnej twórczości Rawlsa, który oznaczał wzięcie przez niego w nawias filozoficznych i moralnych kontrowersji oraz próbę sformułowania koncepcji sprawiedliwości w kategoriach jedynie politycznych ${ }^{4}$. Charakter i znaczenie owego zwrotu można postrzegać różnie. Można go intepretować jako radykalne odejście od dotychczasowego sposobu uprawiania przez Rawlsa filozofii, na przykład jako odejście od teorii sprawiedliwości, której celem było sformułowanie uniwersalnych zasad sprawiedliwości, ku partykularystycznie rozumianej filozofii politycznej, uznającej za punkt wyjścia i jednocześnie punkt odniesienia historycznie ukształtowaną kulturę polityczną zachodnich społeczeństw demokratycznych. $Z$ drugiej strony można mówić o ewolucji Rawlsowskich poglądów raczej niż o ich radykalnej zmianie. W niniejszym tekście opowiadam się za tym drugim stanowiskiem. $Z$ tego też powodu - o tyle, o ile jest to możliwe - będę traktował Rawlsowską koncepcję uzasadnienia jako całość, abstrahując od zmian w jej rozumieniu. Tam natomiast, gdzie dla jasności wywodu potrzebne będzie wyjaśnienie pewnych zmian w myśleniu Rawlsa, tam takie wyjaśnienia poczynię.

4 Znaczenie politycznego charakteru owych idei zostanie wyjaśnione w dalszych partiach tekstu. 


\section{NATURA PRAKTYCZNEGO UZASADNIENIA}

Czym jest uzasadnienie? Jak należy je rozumieć? Przez uzasadnienie rozumieć można przedstawienie racji, które pozwalają na uznanie tego, co uzasadniane. Uznać na przykład można czyjeś postępowanie za słuszne, pewne instytucje i praktyki społeczne za sprawiedliwe, a twierdzenia zaś za prawdziwe. Rawls jednak nie utożsamia uzasadnienia po prostu $\mathrm{z}$ dowodem czy z poprawną argumentacją ${ }^{5}$. Uzasadnienie jest czymś więcej niż przedstawieniem dowodów na rzecz danej tezy. Nie można też sprowadzić go do formalnej poprawności argumentacji czy rozumowania. Wprawdzie uzasadnienie na nich się opiera, lecz nie wystarcza dlań poprawne rozumowanie i nie kończy się wraz z przedstawieniem dowodów czy racji. Konieczność uzasadnienia rodzi się z potrzeby zaradzenia rozbieżności naszych przekonań i sądów i owej rozbieżności ma zaradzić. Brak spójności jest normalną przypadłością naszego myślenia: „Ci, którzy zakładają, że ich sądy są zawsze spójne - stwierdza Rawls - są bezrefleksyjni i dogmatyczni, nierzadko to ideolodzy i zeloci”. Rozbieżność między przekonaniami zachodzi nie tylko w obrębie naszego własnego myślenia, lecz pomiędzy naszymi przekonaniami a przekonaniami innych. Uzasadnienie jest więc próbą pogodzenia nas przy pomocy rozumu $z$ innymi lub $z$ nami samymi. Oznacza więc ono rozumną zgodność między naszymi przekonaniami a przekonaniami innych. Jeśli zaś w niezgodzie byliśmy sami ze sobą, oznacza rozumną zgodność naszych przekonań.

Rawls zainteresowany był jednak nie tyle problemem uzasadnienia w ogóle, ile problemem uzasadnienia praktycznego, czyli wyjaśnieniem, jak możliwe jest osiągnięcie porozumienia, które stanowić ma podstawę działania politycznego. Czym zatem dokładnie jest

5 J. Rawls, Teoria sprawiedliwości, dz. cyt., 784-785.

6 Tenże, Justice as Fairness. A Restatement, red. Erin Kelley, Harvard University Press, Cambridge 2001, 30. 
uzasadnienie praktyczne? Odpowiedź na to pytanie zależy zarówno od właściwego zrozumienia celu teorii sprawiedliwości, jak i od filozofii politycznej ${ }^{7}$, w ramach których uzasadnienie ma miejsce.

Celem teorii sprawiedliwości jest przedstawienie takiej koncepcji sprawiedliwości, która mogłaby stanowić podstawę porozumienia pomiędzy obywatelami co do kształtu instytucji ekonomicznych i politycznych, a więc warunków ich wspólnotowego działania. Odwołując się do pierwszych zasad tej koncepcji, obywatele mogliby osądzać roszczenia podnoszone wobec siebie, jak i w stosunku do instytucji państwa. Pierwsze zasady sprawiedliwości to zasady, które „przypisują prawa i obowiązki oraz określają właściwy podział społecznych korzyści”" albo też zasady, które pozwalają określić „niezbędne elementy konstytucji i kwestie sprawiedliwości podstawowej"9. Do niezbędnych elementów konstytucji należy zaliczyć „podstawowe zasady, które określają ogólną strukturę władzy państwowej i procesu politycznego”, a także „równe podstawowe prawa i wolności obywateli" ${ }^{10}$, zaś do kwestii sprawiedliwości podstawowej należy zaliczyć kwestie nierówności społecznej i ekonomicznej ${ }^{11}$. Innymi słowy, zasady sprawiedliwości określają instytucjonalny kształt społeczeństwa, w ramach którego obywatele działają.

Porozumienie co do podziału społecznych korzyści i ciężarów musi spełniać określone warunki, aby można było uznać je za wiążące. Nie może być więc rezultatem gry przypadkowych czynników, ani wynikać z przewagi jednej ze stron porozumienia. Musi być fair, a więc musi być takim porozumieniem, które jest uczciwe i rozsądne. Musi być to porozumienie, które byłoby do przyjęcia przez

7 Pojęciami „teoria sprawiedliwości” oraz „filozofia polityczna” będę w niniejszym tekście posługiwał się zamiennie, z całą świadomością uproszczeń, które z konieczności pociąga za sobą takie utożsamienie.

8 J. Rawls, Teoria sprawiedliwości, dz. cyt., 22.

9 Tenże, Liberalizm polityczny, dz. cyt., 312.

10 Tamże.

11 Tamże, 314. 
każdego obywatela, kierującego się racjonalnymi racjami. Innymi słowy, musi być to porozumienie, które miałoby normatywną moc. Jak jest to możliwe?

Rawls za punkt wyjścia swych rozważań przyjmuje ${ }^{12}$ istnienie w społeczeństwie demokratycznym pluralizmu światopoglądowego oraz religijnego. Obywatele mają odmienne przekonania na temat świata i własnego w nim miejsca, inaczej postrzegają relacje z innymi i różnym rzeczom przypisują wartość w życiu. Sam fakt pluralizmu byłby z normatywnego punktu widzenia bez znaczenia, byłby jeszcze jedną przypadłością naszego życia, gdyby nie to, że jest on rezultatem użycia rozumu w warunkach wolności. W społeczeństwach demokratycznych nie mamy bowiem do czynienia ze zwykłym pluralizmem, lecz z rozumnym pluralizmem: „rozmaitość rozumnych rozległych doktryn (comprehensive doctrines) religijnych, filozoficznych i moralnych obecnych w nowoczesnych społeczeństwach demokratycznych nie jest tylko pewną okolicznością historyczną, która może wkrótce przeminąć; jest to trwała cecha publicznej kultury demokracji. W politycznych i społecznych warunkach zapewnionych przez podstawowe prawa i swobody wolnych instytucji rozmaitość ścierających się ze sobą i nie dających się pogodzić - a przy tym rozumnych - rozległych doktryn z czasem dojdzie do głosu i utrzyma się, jeśli już nie tak się dzieje"13.

Źródłem rozumnego pluralizmu nie są różnice w materialnych interesach między ludźmi. Nie jest więc rozbieżność religijnych, moralnych i filozoficznych doktryn konsekwencją egoizmu, jak i nie

12 W okresie Liberalizmu politycznego istnienie pluralizmu religijnego, filozoficznego czy światopoglądowego explicite jest uznane za fakt, który w procesie uzasadniania trzeba uwzględnić. Można jednak argumentować, że także i w Teorii sprawiedliwości takie założenie jest poczynione.

13 J. Rawls, Liberalizm polityczny, dz. cyt., 74. Pojęcie 'rozległej doktryny' jest pojęciem technicznym, używanym przez Rawlsa na określenie tej części naszych przekonań, które mówią o wartościach, ideałach, cnotach. Jej pojęcie zyskuje na jasności, gdy przeciwstawi się ją tej części naszych przekonań, które uznać można za polityczne, obejmujące kwestie regulowane przez zasady sprawiedliwości. 
jest konsekwencją stronniczości czy ludzkiej skłonności do partykularyzmu, lecz jest „w jakiejś części dziełem wolnego praktycznego rozumu działającego w ramach wolnych instytucji”'14. Przez to różnorodności przekonań nie należy traktować jako fatalnej przypadłości naszego świata, lecz uznać ją za wynik aktywności ludzkiego rozumu $\mathrm{w}$ warunkach wolności $\mathrm{i}^{15}$. Wobec tego podstawą porozumienia w społeczeństwie demokratycznym nie może być żadna z owych rozległych doktryn. Przyjęcie jej za wspólną podstawę wymagałoby, powiada Rawls, „opresyjnego użycia władzy państwowej”16 oraz ograniczenia wolności. Słowem, zmuszenia ludzi do wyznawania jednej doktryny i ograniczenia wolności myśli i słowa.

Jak więc osiągnąć porozumienie, nie odwołując się do naszych religijnych czy filozoficznych przekonań? Powiedziałem, że konieczność uzasadnienia rozumianego jako porozumienie rodzi rozbieżność naszych przekonań, a dokładniej rzecz ujmując rozbieżność przekonań co do instytucjonalnego kształtu społeczeństwa demokratycznego. Konsens nie jest jednak tylko celem uzasadnienia, lecz także tym, co stanowi podstawę i punkt wyjścia dla uzasadnienia ${ }^{17}$. Istnieć musi pewien wspólny grunt, który umożliwia dalsze porozumienie. Tym wspólnym punktem odniesienia są przede wszystkim pewne normatywne wyobrażenia czy też ideały podzielane przez obywateli w społeczeństwie demokratycznym. Odwołując się do nich, wyprowadzając z nich odpowiednie konsekwencje, organizując je w spójną całość, można wypracować taką koncepcję sprawiedliwości, która stanowiłaby podstawę porozumienia w społeczeństwie demokratycznym.

Rawls wskazuje na dwie główne „idee”, stanowiące owe ideały czy wyobrażenia normatywne: „społeczeństwa jako sprawiedliwego

14 Tamże, 75.

15 Wyjaśnieniu, czemu rozum w warunkach wolności prowadzi do rozbieżności, służy quasi-epistemologiczna koncepcja ciężarów sądów.

16 J. Rawls, Liberalizm polityczny, dz. cyt., 75.

17 Tenże, Justice as Fairness: Political not Metaphysical, w: tenże, Collected Papers, red. S. Freeman, Harvard University Press, Cambridge 1999, 394. 
systemu kooperacji w czasie, z pokolenia na pokolenie" oraz ideę osoby, a dokładniej wolnych i równych obywateli, posiadających dwie władze moralne ${ }^{18}$. Przez dwie władze moralne rozumie Rawls: rozumność, czyli gotowość do zaproponowania i honorowania sprawiedliwych warunków społecznej kooperacji, na które i inni mogliby przystać, a także gotowość do przyjęcia i honorowania sprawiedliwych warunków kooperacji zaproponowanych przez innych; oraz racjonalność, czyli zdolność obierania celów życiowych, ich hierarchizowania, a także doboru środków do ich osiągnięcia. Ów wspólny punkt wyjścia nie tylko daje nadzieję na osiągnięcie porozumienia co do instytucjonalnych warunków działania politycznego, lecz także dzięki temu, że odwołuje się od pewnych ideałów, gwarantuje jego normatywny charakter.

Celem uzasadnienia praktycznego jest więc osiągnięcie porozumienia co do pewnej koncepcji sprawiedliwości, które to porozumienie stanowić będzie podstawę działania politycznego. Porozumienie to osiągnięte zostaje w warunkach nieusuwalnego, będącego konsekwencją wolnego użycia rozumu pluralizmu światopoglądowego, a dzięki odwołaniu się do pewnych ideałów podzielanych przez obywateli społeczeństwa demokratycznego porozumienie to ma charakter normatywny. A dokładniej rzecz ujmując, porozumienie to ma charakter normatywny i polityczny, co oznacza, że dotyczy kwestii konstytucyjnych i sprawiedliwości podstawowej, a więc jest porozumieniem co do sposobu i granic użycia przymusu państwowego. U Rawlsa jednak polityczny charakter uzasadnienia oznacza także, że odnosi się ono jedynie do owych - politycznych właśnie - idei i abstrahuje od rozumnych i rozległych doktryn.

Celem uzasadnienia praktycznego jest wykazanie, która koncepcja sprawiedliwości jest koncepcją najrozumniejszą ${ }^{19}$, czyli taką która

18 Często Rawls mówi także o idei „społeczeństwa dobrze urządzonego”, czyli społeczeństwa, które rządziłoby się publicznie uznanymi zasadami sprawiedliwości.

19 Według Rawlsa zadaniem naszym nie jest wykoncypowanie całkowicie nowej koncepcji sprawiedliwości, lecz rozstrzygnięcie, która ze znanych nam z tradycji filozoficznej koncepcja sprawiedliwości (lub jakaś jej uwspółcześniona odmiana) jest najrozumniejsza. 
najlepiej odpowiada naszym normatywnym i politycznym przekonaniom. Jednakże dla Rawlsa uzasadnienie nie jest czymś, co ma niejako charakter tylko filozoficzny, lecz czymś, co ma być urzeczywistnione w wymiarze polityczno-społecznym. Jeśli przez uzasadnienie rozumieć osiągnięcie porozumienia i jeśli dotyczyć ma ono zasad sprawiedliwości rządzących społeczeństwem demokratycznym, to wówczas uzasadnienie oznaczać będzie osiągnięcie przez obywateli porozumienia co do fundamentalnych kwestii politycznych. Tak rozumiane uzasadnienie przebiega $\mathrm{w}$ trzech krokach.

Po pierwsze, obywatele muszą wypracować nie odwołującą się do żadnej z rozległych doktryn koncepcję sprawiedliwości, tj. taką koncepcję, której uznanie nie zależałoby od akceptacji którejś z funkcjonujących w społeczeństwie demokratycznym rozległych doktryn. Innymi słowy, uzasadniając na tym etapie koncepcję sprawiedliwości obywatele nie powinni odwoływać się do swoich przekonań filozoficznych czy religijnych. Następnie koncepcja ta musi zostać uzasadniona w kategoriach czysto politycznych, czyli przez rozum publiczny (rozum odwołujący się jedynie do wartości politycznych, nie zaś do którejś z rozległych doktryn). Ten rodzaj uzasadnienia określony zostaje jako „uzasadnienie pro tanto” ${ }^{20}$, czyli uzasadnienie częściowe. Koncepcja sprawiedliwości zostaje zatem wypracowana przez filozofię polityczną w oparciu jedynie o obecne w kulturze społeczeństwa demokratycznego idee. Nie jest ona ani wyprowadzona z jakiejś rozległej doktryny religijnej, filozoficznej czy moralnej, ani też nie jest przedstawiona jako coś, co wszystkim tym doktrynom jest

Warto też tutaj odnotować rzecz następującą: w praktycznym uzasadnieniu nie chodzi o wykazanie, która z koncepcji sprawiedliwości jest prawdziwa, lecz która z nich jest rozumna. Kategoria rozumności jest przez Rawlsa wprowadzona po to, aby odróżnić uzasadnienie praktyczne od uzasadnienia rozumianego w kategoriach epistemologicznych. Dzieje się tak z dwóch powodów. Po pierwsze, celem uzasadnienia praktycznego jest działanie, nie zaś poznanie. Po drugie, wśród obywateli panuje także rozbieżność filozoficznych opinii na temat prawdy, więc próba oparcia koncepcji sprawiedliwości na takim gruncie jak określona koncepcja prawdy z góry skazana byłaby na niepowodzenie.

20 J. Rawls, Reply to Habermas, Journal of Philosophy 93(1995), 140. 
wspólne. Nie należy więc postrzegać zadania filozofii politycznej jako wydobycia wspólnego wszystkim rozumnym rozległym doktrynom jądra. Filozofia polityczna jest od wszystkich tych doktryn całkowicie niezależna i postępuje samodzielnie w oparciu jedynie o obecne w politycznej kulturze społeczeństwa demokratycznego idee. Dopiero wówczas, gdy w sposób autonomiczny zostanie wypracowana odpowiednia, tj. rozumna (uzasadniona pro tanto), polityczna koncepcja sprawiedliwości, może zostać ona powiązana z określoną rozumną doktryną, czyli zostać w jej kategoriach uzasadniona ${ }^{21}$.

Po drugie, obywatele muszą - każdy z osobna - powiązać publicznie uznaną koncepcję sprawiedliwości z własną rozległą doktryną, czyli uzasadnić koncepcję sprawiedliwości poprzez odwołanie się do wyznawanej przez siebie rozległej doktryny. Uzasadnienie takie przebiega zgodnie $z$ właściwymi dla danej rozległej doktryny warunkami uzasadnienia. Ten rodzaj uzasadnienia zostaje określony jako „pełne uzasadnienie koncepcji politycznej przez indywidualną osobę w społeczeństwie obywatelskim" ${ }^{22}$. Pełne, bowiem koncepcja sprawiedliwości nie jest tylko uzasadniona w kategoriach politycznych, lecz także została powiązana $\mathrm{z}$ innymi przekonaniami (np. religijnymi) żywionymi przez obywateli i to powiązana na sposób właściwy dla danej rozległej doktryny. Ktoś mógłby na przykład uznać, że zasady sprawiedliwości są zgodne z jego religią, bowiem odpowiadają objawieniu. Na tym etapie uzasadnienie to jest właściwe, choć nie jest ono podzielane przez innych obywateli.

21 Można powiedzieć, że obywatele „częściowo” uzasadniając koncepcję sprawiedliwości, stają się filozofami. Warto podkreślić, że dla Rawlsa filozof nie pełni funkcji politycznego eksperta, lecz jest po prostu obywatelem, którego głos w publicznej debacie liczy się tak samo jak innych obywateli. Obywatel nie jest jednak tylko filozofem (w znaczeniu kogoś, kto zajmuje się po Rawlsowsku rozumianą filozofią polityczną), żywi bowiem inne niż tylko filozoficzne (znów w sensie Rawlsowskiej „filozofii politycznej”) przekonania. Stąd potrzeba dalszych kroków w procesie uzasadnienia.

22 J. Rawls, Reply to Habermas, art. cyt., 140. 
Po trzecie, wszyscy obywatele - jako całość - muszą przeprowadzić pełne uzasadnienie politycznej koncepcji sprawiedliwości. Jeśli tak się stanie, koncepcja sprawiedliwości zostanie uznana przez wszystkie rozumne rozległe doktryny funkcjonujące $\mathrm{w}$ danym demokratycznym społeczeństwie. Wówczas mamy do czynienia $\mathrm{z}$ „publicznym uzasadnieniem koncepcji politycznej przez społeczeństwo polityczne"23. W tym przypadku rodzi się następujące oto pytanie: czy z publicznym uzasadnieniem nie mamy już do czynienia w przypadku, gdy po prostu wszyscy obywatele przeprowadzą pełne uzasadnienie danej politycznej koncepcji sprawiedliwości? Nie - odpowiada Rawls - wówczas bowiem mielibyśmy do czynienia z powszechnie przeprowadzonym pełnym uzasadnieniem, nie zaś z publicznym uzasadnieniem. Jaka więc zachodzi różnica między tymi dwoma rodzajami uzasadnienia, jeśli nie jest to różnica zakresu?

Obywatele indywidualnie przeprowadzając pełne uzasadnienie danej politycznej koncepcji sprawiedliwości, nie biorą pod uwagę, czy inni też tę koncepcję uznają. Fakt jej uznania czy też odrzucenia nie ma w tym przypadku żadnego znaczenia dla uzasadnienia. Uznanie przez innych danej koncepcji nie czyni jej bardziej uzasadnioną, zaś jej odrzucenie przez innych nie jest powodem, dla którego winniśmy ją odrzucić jako nieuzasadnioną. Inaczej rzecz natomiast się ma, gdy w grę wchodzi publiczne uzasadnienie. Tutaj „rozumni obywatele biorą pod uwagę to, że każdy wyznaje rozumną rozległą doktrynę, uznającą polityczną koncepcję"24. To nie poszczególni obywatele dążą do osiągnięcia zgodności między daną koncepcją sprawiedliwości a ich rozważnymi sądami w wyniku należytej refleksji, lecz „wszyscy obywatele jako jedno ciało"25. Innymi słowy, wzgląd na innych powoduje, że to społeczeństwo obywatelskie jako takie dokonało

23 Tamże.

24 Tamże, 143.

25 Tamże, 144. 
w procesie dochodzenia do porozumienia uzasadnienia danej koncepcji sprawiedliwości.

Jak widać, trzyetapowy proces uzasadnienia odpowiada Rawlsowskiemu rozumieniu uzasadnienia praktycznego. Uzasadnienie ma zaradzić rozbieżności przekonań - czy to naszych własnych, czy to pomiędzy obywatelami, a przekonania te dotyczą koncepcji sprawiedliwości, która stanowi normatywną podstawę ekonomicznych i politycznych instytucji społeczeństwa demokratycznego.

\section{REFLEKSYJNA RÓWNOWAGA}

Istotnym dla zrozumienia tego, co Rawls rozumiał przez uzasadnienie, jest pojęcie refleksyjnej równowagi. Do tej pory przez uzasadnienie rozumieliśmy proces dochodzenia do porozumienia, mówiliśmy o wprowadzaniu spójności między naszymi przekonaniami czy też między naszymi przekonaniami a przekonaniami innych. $Z$ powyższych uwag na temat pełnego i publicznego uzasadnienia można wnosić, iż w uzasadnieniu koncepcji sprawiedliwości chodzi o pogodzenie jej pierwszych zasad z podzielanymi przez obywateli pewnymi normatywnymi wyobrażeniami - czy to innymi politycznymi przekonaniami (na przykład na temat społeczeństwa czy osoby) w przypadku uzasadnienia pro tanto, czy tymi, które stanowią część danej rozległej doktryny w przypadku pełnego uzasadnienia. Rawls nazywa ów stan zgodności refleksyjna równowagq. Wyjaśnijmy zatem pokrótce, czym jest refleksyjna równowaga.

Powiada Rawls, że „uzasadnienie jest kwestią wzajemnego wspierania się wielu względów, połączenia wszystkiego w jeden spójny pogląd"26. O danej koncepcji sprawiedliwości możemy zatem powiedzieć, że jest uzasadniona wówczas, gdy poszczególne jej elementy wzajemnie się „wspierają", tworząc spójną całość, a także wtedy, gdy pozostaje ona w zgodności z pozostałymi naszymi przekonaniami.

26 J. Rawls, Teoria sprawiedliwości, dz. cyt., 813. 
Stan taki określany jest jako stan refleksyjnej równowagi: równowagi dlatego, że „w końcu nasze zasady i sądy się zgadzają", refleksyjnej dlatego, że „wiemy, do jakich sądów dostosowują się nasze sądy i z jakich przesłanek je wywiedziono"27. Stan taki osiągnięty zostaje dzięki określonej metodzie postępowania - metodzie refleksyjnej równowagi - polegającej na wzajemnym „dopasowywaniu” różnych elementów danej teorii tak, aby w końcu osiągnąć pożądaną spójną całość.

Refleksyjna równowaga polega zatem na osiągnięciu w wyniku refleksji zgodności między naszymi przekonaniami, które wyrażone są pod postacią tzw. rozważnych sądów ${ }^{28}$, a pierwszymi zasadami danej koncepcji sprawiedliwości. Charakter owej równowagi zależy od stopnia złożoności całości naszych przekonań. Przekonania te znajdować się mogą na różnym stopniu abstrakcji oraz ogólności i dotyczyć rozmaitych przedmiotów. W przypadku koncepcji sprawiedliwości takiej jak na przykład Rawlsowska koncepcja justice as fairness („sprawiedliwości jako bezstronności”) chodzi o zgodność między zasadami sprawiedliwości a 1) rozważnymi sądami wyrażającymi rozumne i racjonalne warunki, jakie dana koncepcja sprawiedliwości musi spełnić, 2) rozważnymi sądami na temat sprawiedliwości pewnych instytucji oraz praktyk, 3) rozważnymi sądami wyrażającymi pewne normatywne idee takie jak idea społeczeństwa jako sprawiedliwego systemu kooperacji czy idea równych i wolnych obywateli; 4) sądami wyrażającymi pewne ogólne tezy z zakresu socjologii i psychologii moralnej. O zasadach sprawiedliwości możemy powiedzieć, że są

27 Tamże, 53.

28 Rozważne sądy (considered judgment) to kolejna techniczna kategoria, którą posługuje się Rawls. Oznacza ona takie sądy, które wydane zostały w warunkach sprzyjających sądzeniu, a więc bezstronne, wydane po uwzględnieniu relewantnych czynników, takie, w których pokładamy zaufanie itp. Przykładem takiego sądu na temat sprawiedliwości praktyk społecznych jest na przykład sąd mówiący, że niewolnictwo jest złe. Uwzględnienie tylko rozważnych sądów zamiast po prostu wszystkich sądów ma na celu zwiększenie mocy uzasadniającej refleksyjnej równowagi. 
uzasadnione wówczas, gdy odpowiadają naszym rozważnym sądom oraz gdy pozwalają na formułowanie nowych sądów na temat sprawiedliwości instytucji i praktyk społecznych. Owe przekonania czy też wyrażające je sądy z kolei znajdują swoje uzasadnienie dzięki owym zasadom. Stan refleksyjnej równowagi zostaje osiągnięty dzięki wzajemnemu uzgadnianiu zarówno sądów, jak i zasad.

Refleksyjną równowagę osiąga się zatem w procesie wzajemnego uzgadniania zasad oraz naszych rozważnych sądów, a dokładniej rzecz ujmując, w procesie wzajemnego uzgadniania wszystkich elementów o różnym stopniu ogólności i abstrakcji. Stwierdzenie to jednak należy doprecyzować. Osiągniętej w danym momencie czasu refleksyjnej równowagi nie należy traktować jako ostatecznej czy też jako końca procesu uzasadnienia, lecz jako mającej charakter tymczasowy. Dla Rawlsa refleksyjna równowaga jest „punktem w nieskończoności, którego nigdy nie możemy osiągnąć, choć możemy się do niego zbliżać w tym oto sensie, że dzięki dyskusji nasze ideały, zasady oraz sądy jawią się nam jako bardziej rozumne i lepiej uzasadnione niż były wcześniej”29. W tym sensie też dążenie do osiągnięcia refleksyjnej równowagi pomiędzy naszymi rozważnymi sądami a rozważnymi sądami naszych współobywateli jest częścią demokratycznego procesu dochodzenia do porozumienia (publicznej debaty). Procesu, który jest jednocześnie podstawą trwania i żywotności demokratycznych instytucji, jak i przez te instytucje (na przykład przez konstytucyjne gwarancje wolności słowa) jest chroniony. Pojęcie refleksyjnej równowagi ma pozwolić nam zrozumieć demokratyczny proces dochodzenia do porozumienia, na który z filozoficznej perspektywy spojrzeć można jako na proces uzasadnienia, czyli proces wykształcania się normatywnej podstawy funkcjonowania instytucji społeczeństwa demokratycznego.

Dlaczego jednak osiągnięcie równowagi, nawet jeśli jest ona refleksyjna i jest wynikiem procesu demokratycznej deliberacji, ma

29 J. Rawls, Reply to Habermas, ar. cyt., 142. 
decydować o uzasadnieniu danej koncepcji? Przecież możemy pomyśleć sobie sytuację, w której do czynienia będziemy mieli ze spójną i przemyślaną koncepcją sprawiedliwości, która dyskryminować będzie na podstawie rasowej pewną grupę społeczną. Trudno byłoby uznać taką koncepcję za uzasadnioną, a tym samym za rozumną, nawet jeśli byłaby ona spójna i przemyślana. $\mathrm{W}$ uzasadnieniu chodzić musi więc o coś więcej, aniżeli tylko o zwykłą spójność między naszymi przekonaniami. Dlatego też Rawls wprowadza pojęcie szerokiej i powszechnej refleksyjnej równowagi.

Aby wyjaśnić, czym jest szeroka refleksyjna równowaga, należy odróżnić ją od wąskiej refleksyjnej równowagi. W przypadku tej ostatniej bierzemy pod uwagę tylko jeden zespół zasad czy też koncepcję sprawiedliwości, która na pierwszy rzut oka najlepiej odpowiada naszym rozważnym sądom, czy też, jak to ujmuje Rawls, wymaga jak najmniej zmian ${ }^{30}$. Oczywiście, dążąc do osiągnięcia równowagi pomiędzy naszymi rozważnymi sądami o rożnym stopniu ogólności a koncepcją sprawiedliwości dochodzić może do zmian naszych rozważnych sądów czy nawet modyfikacji zasad, jednakże są to jedynie drobne zmiany, polegające na eliminacji drobnych sprzeczności czy „wygładzaniu” całości.

$\mathrm{Z}$ szeroką refleksyjną równowagą mamy natomiast do czynienia wówczas, gdy dana osoba dążąc do jej osiągnięcia „dokładnie rozważyła alternatywne koncepcje sprawiedliwości i siłę różnych argumentów na ich rzecz. Ujmując rzecz dokładniej, osoba ta rozważyła wiodące koncepcje sprawiedliwości politycznej obecne w naszej tradycji filozoficznej (włączając w to poglądy krytyczne wobec samego pojęcia sprawiedliwości, jako przykład niech posłuży pogląd Marksa) oraz oszacowała siłę różnych filozoficznych i innych argumentów na ich rzecz. Zakładamy tutaj, że ogólne przekonania, pierwsze zasady i poszczególne sądy się zgadzają; lecz w tym przypadku refleksyjna

30 Tenże, Justice as Fairness. A Restatement, art. cyt., 30. 
równowaga jest szeroka, zważywszy na szeroki zakres refleksji i wielość możliwych zmian, będących jej wynikiem"31.

Biorąc pod uwagę zadania, jakie stoją przed filozofią polityczną, dążenie do refleksyjnej równowagi polega na wyborze spośród zasad sprawiedliwości przekazanych nam przez tradycję refleksji filozoficznej i politycznej takich zasad, które najlepiej odpowiadałyby obecnym w naszych rozważnych sądach ideałom (na przykład społeczeństwa jako sprawiedliwego systemu kooperacji), a także tym rozważnym sądom, które wyrażają nasze przekonania na temat sprawiedliwości poszczególnych instytucji i praktyk społecznych oraz wyrażaja ogólne przekonania z zakresu socjologii i psychologii moralnej, oraz spełniają pewne określone rozumne i racjonalne wymogi ${ }^{32}$. Wybór zasad ma miejsce w wyniku należytej refleksji nad argumentami przedstawionymi na rzecz każdej z poszczególnych koncepcji, jak i argumentami przeciwko koncepcjom konkurencyjnym, a nawet pojęciu sprawiedliwości w ogóle i przy zastosowaniu wyrafinowanych filozoficznie narzędzi intelektualnych.

Kategorią refleksyjnej równowagi posługujemy się w przypadku każdego z trzech wyróżnionych przez nas rodzajów uzasadnienia. W przypadku uzasadnienia pro tanto, jak i pełnego uzasadnienia politycznej koncepcji sprawiedliwości, mówić możemy zarówno o wąskiej, jak i szerokiej refleksyjnej równowadze. W przypadku uzasadnienia pro tanto (uzasadnienia częściowego), czyli uzasadnienia tylko w kategoriach politycznych, możemy mówić o politycznej równowadze refleksyjnej, która może być zarówno szeroka

31 Tamże, 31.

32 Ograniczenie rozważanych koncepcji do tych, które przekazała nam historia refleksji filozoficznej i politycznej, oprócz metodologicznego ma jeszcze uzasadnienie praktyczne. To właśnie filozoficzna refleksja częściowo kształtowała publiczną i polityczną kulturę społeczeństw zachodnich, z której czerpiemy nasze przekonania, a zatem odwołanie się do historii filozofii i refleksji politycznej ułatwia nam osiągnięcie porozumienia. Z pewnością porozumienie jest łatwiejsze niż gdyby normatywny konsens miałby się ukonstytuować wokół nowatorskich zasad sprawiedliwości. 
jak i wąska. Polega ona na zgodności między naszymi rozważnymi sądami a pierwszymi zasadami politycznej koncepcji sprawiedliwości i odnosi się wyłącznie do tego, co ma charakter polityczny (w odróżnieniu od tego, co wyrażone w rozległych doktrynach).

Inaczej rzecz się ma w przypadku pełnego uzasadnienia. Pełne uzasadnienie polega na powiązaniu wyznawanej przez danego obywatela rozległej doktryny z polityczną koncepcją sprawiedliwości. W tym przypadku wykraczamy poza obszar tego, co polityczne i nie ograniczamy się tylko do politycznie rozumianej rozumności. Innymi słowy, zmieniamy perspektywę i nie operujemy kategoriami rozumu publicznego, lecz kategoriami określonymi przez daną rozległą doktrynę. Stąd też $-z$ perspektywy indywidualnego obywatela w społeczeństwie obywatelskim wyznające określoną rozległą doktrynę - rozważne sądy nie muszą być postrzegane jako tylko odznaczające się wewnętrzną rozumnością lub akceptowalnością, lecz mogą być traktowane jako na przykład prawdziwe. Tak też jest w przypadku samej koncepcji sprawiedliwości, która może być traktowana jako prawdziwa. Epistemologiczna kwestia prawdziwości koncepcji sprawiedliwości pozostawiona zostaje do rozstrzygnięcia przez indywidualnych obywateli w kategoriach wyznawanych przez nich rozległych doktryn. Refleksyjna równowaga, która i w tym przypadku może być szeroka lub wąska, polega zatem na osiągnięciu zgodności między rozważnymi sądami o różnym stopniu ogólności i abstrakcji danej rozległej doktryny a polityczną koncepcją sprawiedliwości. Podkreślić należy raz jeszcze, że polityczna koncepcja sprawiedliwości w przypadku pełnego uzasadnienia nie jest traktowana po prostu jako rozumna, lecz w kategoriach właściwych dla danej rozległej doktryny (na przykład w kategoriach prawdziwości lub zgodności z objawieniem).

W przypadku publicznego uzasadnienia, kiedy to polityczna koncepcja sprawiedliwości zostaje uzasadniona przez społeczeństwo obywatelskie jako takie, czyli wtedy, gdy wszyscy obywatele przeprowadzą pełne jej uzasadnienie, uznając jednocześnie przy tym to, że inni podjęli się i dokonali takiego uzasadnienia mamy do czynienia 
z powszechną refleksyjną równowagą, czyli z sytuacją, gdy „ta sama koncepcja jest potwierdzona przez rozważne sądy każdego"33.

W sytuacji, gdy dana koncepcja sprawiedliwości znajdzie się w szerokiej i powszechnej refleksyjnej równowadze refleksyjna równowaga jest „pełna”. Innymi słowy, możemy wtedy powiedzieć, że dana koncepcja jest uzasadniona. Jak więc widać, proces dochodzenia do porozumienia i tym samym proces uzasadnienia jest procesem złożonym. Wymaga wypracowania określonej koncepcji sprawiedliwości, a więc połączenia w spójną całość elementów o różnym stopniu ogólności i abstrakcji (takich jak, z jednej strony, zasady sprawiedliwości, z drugiej zaś ideały społeczeństwa i obywatela, racjonalne i rozumne wymogi, jakie musi spełnić dana koncepcja sprawiedliwości itp.), pogodzenia jej z własną rozległą doktryną, a w wymiarze publicznym wypracowania między obywatelami wyznającymi różne rozległe doktryny konsensu, który by ją obejmował.

Zaproponowana przez Rawlsa ${ }^{34}$ koncepcja refleksyjnej równowagi zdobyła szczególną popularność wśród autorów zajmujących się filozofią praktyczną $a^{35}$. Spotkała się także, co oczywiste, z kry-

33 Tamże.

34 Źródeł koncepcji refleksyjnej równowagi szukać można już w Sokratejskiej metodzie badania moralnego, Arystotelesowskiej metodologii filozofii praktycznej czy u Henry Sidgwicka.

35 Gilbert Harman w artykule Three Trends in Moral and Political Philosophy stwierdza, że Rawlsowska koncepcja refleksyjnej równowagi jest jednym z trzech najważniejszych trendów we współczesnej filozofii moralnej. Pozostałe dwa to 2) koncepcje odwołujące się do naszych intuicji, które ujawniają się przy rozstrzyganiu konkretnych problemów moralnych, i formułujące w oparciu o owe intuicje nowych zasad moralnych oraz 3) koncepcje opierające się na badaniach naukowych dotyczących moralności, na przykład z zakresu psychologii. Por. G. Harman, Three Trends in Moral and Political Philosophy, The Journal of Value Inquiry 37(2003), 415-425. Do autorów odwołujących się do Rawlsa można zaliczyć między innymi Normana Danielsa (Justice and Justification: Reflective Equilibrium in Theory and Practice, Cambridge University Press, New York 2006) oraz Thomasa M. Scanlona (The Aims and Authority of Moral Theory, Oxford Journal of Legal Studies 12(1992)1, 1-23, Moral Theory: Understanding and Disagreement, Philosophy and Phenomenological Research 55(1995)2, 343-356. 
tykąa ${ }^{36}$ Nie sposób przedstawić tutaj całej złożoności owej krytyki, wskażę więc jedynie na główne jej wątki. Fundamentalny zarzut pod adresem metody refleksyjnej równowagi mówi, że nie ma ona mocy uzasadniającej, bowiem jedyne co dzięki niej możemy osiągnąć to wprowadzenie spójności w nasze przekonania. To zaś nie daje nam gwarancji, że nasze przekonania zyskują na racjonalności czy prawdziwości. Zarzut ten wzmacnia jeszcze to, że nie jest wcale takie oczywiste, że nasze „rozważne sądy”, które stanowić mają punkt odniesienia dla osiągnięcia refleksyjnej równowagi, są rzeczywiście rozważne. Po pierwsze dlatego, że nie ma zgody co do tego, jakie kryteria dane sądy powinny spełnić, by można je uznać za „rozważne”. Po drugie dlatego, że nawet jeśliby udałoby się nam osiągnąc zgodę co do owych kryteriów, to i tak możemy natknąć się na praktyczne trudności, które uniemożliwiłyby nam wskazanie, które to sądy faktycznie są rozważne. W konsekwencji - stwierdzają krytycy refleksyjnej równowagi - metoda ta może nie tyle uzasadniać nasze normatywne przekonania, ile utwierdzać nas w naszych przesądach i uprzedzeniach.

Ostrze powyżej przedstawionej krytyki można stępić, wskazując na Rawlsowskie rozumienie uzasadnienia, którego celem nie jest przecież odkrycie „prawdy moralnej” (to zadanie, które leży w gestii poszczególnych rozległych doktryn, o ile istnienie prawdy moralnej one zakładają), lecz osiągnięcie porozumienia co do koncepcji sprawiedliwości, której zasady mają stanowić normatywną podstawę funkcjonowania instytucji społeczeństwa demokratycznego. Niemniej jednak problem z Rawlsowską koncepcją uzasadnienia pozostaje, bowiem trudno - na co wskazuje Jürgen Habermas ${ }^{37}$ - odróżnić

36 Zob. np. R.B. Brandt, A Theory of the Good and the Right, Clarendon Press, Oxford 1979, 16-23; P. Singer, Sidgwick and Reflective Equilibrium, The Monist 58(1974)3, 490-517.

37 J. Habermas, Liberalizm polityczny - polemika z Johnem Rawlsem, w: tenże, Uwzględniając Innego, tłum. z niem. A. Romaniuk, Wydawnictwo Naukowe PWN, Warszawa 2009. 
w takiej sytuacji uzasadnienie koncepcji sprawiedliwości od faktycznej jej akceptacji.

Podsumowując, można powiedzieć, że moc uzasadniająca refleksyjnej równowagi nie jest tak oczywista, jak chcą to widzieć jej zwolennicy, a tym samym pod znakiem zapytania postawiony zostaje normatywny i praktyczny charakter Rawlsowskiej koncepcji uzasadnienia. Porozumienie stanowiące istotę uzasadnienia bowiem ma mieć charakter normatywny. Ma stanowić podstawę rozstrzygania o słuszności i niesłuszności określonych roszczeń, sprawiedliwości i niesprawiedliwości danych instytucji itp. Jeśli zaś porozumienie obywateli nie oznacza nic więcej niż faktyczną akceptację danej koncepcji sprawiedliwości, to skąd brać ma się jej moc wiążąca?

Moja odpowiedź na to pytanie jest następująca. Przedstawiona przez Rawlsa metoda refleksyjnej równowagi nie jest metodą uzasadnienia, lecz jedynie opisem tego, co faktycznie filozofowie robią, gdy podejmują się zadania uzasadnienia pewnej koncepcji sprawiedliwości. Jednakże samo wprowadzenie spójności w nasze sądy o różnym stopniu abstrakcji i ogólności po rozpatrzeniu wszelkich „za” i „przeciw” nie jest tym, co przesądza o uzasadnieniu, lecz natura przedstawionych argumentów. Nie jesteśmy w stanie orzec, czy dana koncepcja sprawiedliwości jest uzasadniona na podstawie tylko tego, że pozostaje ona w refleksyjnej równowadze z naszymi pozostałymi (rozważnymi) przekonaniami. Musimy wiedzieć, jakie racje skłoniły nas do jej uznania. W przypadku Rawlsowskiej koncepcji sprawiedliwości jako bezstronności musimy pod rozwagę poddać zastosowane przez niego procedury teorii kontraktowych i konstruktywistycznych, których zastosowanie służyć ma do osiągnięcia refleksyjnej równowagi $i^{38}$.

38 Problem ten podejmuję w artykule John Rawls: kontraktualizm i konstruktywizm, który stanowi część drugą cyklu przedstawiającego Rawlsowską koncepcję uzasadnienia. 
BIBLIOGRAFIA

Brandt R., A Theory of the Good and the Right, Clarendon Press, Oxford 1979.

Daniels N., Justice and Justification: Reflective Equilibrium in Theory and Practice, Cambridge University Press, New York 2006.

Habermas J., Liberalizm polityczny - polemika z Johnem Rawlsem, w: Tenże, Uwzględniajac Innego, tłum. z. niem., A. Romaniuk, Wydawnictwo Naukowe PWN, Warszawa 2009, 60-110.

Harman G., Three Trends in Moral and Political Philosophy, The Journal of Value Inquiry 37(2003), 415-425.

Rawls J., Justice as Fairness: Political not Metaphysical, w: Tenże, Collected Papers, ed. S. Freeman, Harvard University Press, Cambridge 1999, 388-414.

Rawls J., Justice as Fairness. A Restatement, ed. E. Kelley, Harvard University Press, Cambridge 2001.

Rawls J., Liberalizm polityczny, tłum. A. Romaniuk, Wydawnictwo Naukowe PWN, Warszawa 1999.

Rawls J., Outline of a Decision Procedure for Ethics, Philosophical Review 60(1951), 177-197.

Rawls J., Reply to Habermas, Journal of Philosophy 93(1995), 132-180.

Rawls J., Teoria sprawiedliwości, tłum. z ang. M. Panufnik, J. Pasek, A. Romaniuk, Wydawnictwo Naukowe PWN, Warszawa 1994.

Scanlon Th., Moral Theory: Understanding and Disagreement, Philosophy and Phenomenological Research 55(1995)2, 343-356.

Scanlon Th., The Aims and Authority of Moral Theory, Oxford Journal of Legal Studies 12(1992)1, 1-23.

Singer P., Sidgwick and Reflective Equilibrium, The Monist 58(1974)3, 490-517.

\section{JOHN RAWLS: PRACTICAL JUSTIFICATION FOR THE NOTION OF JUSTICE AND REFLECTIVE EQUILIBRIUM}

Abstract. In this article the author discusses two topics that are important for understanding the nature of practical justification. The first topic concerns the explanation of the nature of practical justification as an agreement to conditions (principles) of political action between citizens in a democratic society. The second topic concerns the explanation of the idea of reflective equilibrium.

Keywords: John Rawls, practical justification, reflective equilibrium 
KRZYSZTOF KĘDZIORA

kedziora@filozof.uni.lodz.pl

Uniwersytet Łódzki, Instytut Filozofii, Katedra Etyki

Lindleya 3/5, 90-131 Łódź

DOI: 10.21697/spch.2016.52.3.01 